\title{
FEATURES OF LEGAL PROCEDURES OF LEGALIZATION BUSINESS PROCEDURES IN UKRAINE AND CHINA: LEGAL ANALYSIS
}

\author{
Manko D. G.
}

\section{INTRODUCTION}

Lawyers people always seek to find the components, which as a chain combine the different legal systems. The important thing is that, without regard to the type of such system's organization it points out the social significance of these procedures which manifestation is the confirmation of the needed existence by society. No doubt arises, that we can know the procedure of the legalization, by doing analysis, of any legal system of law.

Procedures, that put an emphasis on that legal algorithm in accordance to which the actions may have been taken and the result will be erecting certain entities in a state that is in compliance with applicable law. Legalizationprocedures are inherent in any legal system of the modern statedepending on the form of it: state-political regime - democratic orantidemocratic; forms of government - confederate,federal or unitary; forms of government - monarchy or republic. Legalization procedures are of particular importance to the organization effective cooperation between different states and is one of thethe most important mechanisms of qualitative development of globalization and integrationprocesses.

Therefore, in the context of the disclosure of the object of study, it arisesthe need for a thorough characterization of the legalization and legal procedurealgorithms for its implementation, establishing their role in legal regulationsocial relations in the legal systems of Ukraine and China.Issues related to the subject of study were reflected inworks of many scientists in particular: Zhurenok TV, Katkova TG, Koneva AN, Kresina OV, Stepanova TV, Tosunyan GA, Trofimchuk AP, Chirkina V.E., and others.Given the above, the main purpose of the study is to conductcomparative-legal analysis of features of legal algorithms of proceduresbusiness legalization in the legal systems of Ukraine and China.

\section{General principles of interaction between the legal systems of Ukraine andPeople's Republic of China}

For proper disclosure of features legalization of business in the legal systems of Ukraine and the People's Republic of China The Republic (hereinafter referred to as the PRC), it is necessary to analyze the general 
principles of cooperation between our states, characterize their legal systems, determine the content legalization activities and analyze some types of legalization procedures, according to Ukrainian and Chinese law, thanks to which stakeholders will be able to engage in business.

Exploring the principles of cooperation between our countries, it should be noted that China is one of the few partners in Ukraine, deepening relations with which neither Russia, the EU, nor the United States. In addition, unlike European, Euro-Atlantic and Eurasian integration projects, Ukraine's rapprochement with China in no way aggravates the issue of its sovereignty. Therefore, China is viewed as an impartial partner guided by the principles of non-interference, respect for territorial integrity, cooperation and zero-sum play.

The countdown of Ukrainian-Chinese relations begins on December 27, 1991, when China officially recognized our country. The first high-level bilateral contact was marked by the visit of President of Ukraine Leonid Kravchuk to the People's Republic of China in 1992. The bilateral political dialogue between Ukraine and the People's Republic of China continued during the visit of the President of the People's Republic of China, Jiang Zemin, to 1994 and 2001, and the Prime Minister of the People's Republic of China. Li Peng in 1995 to Ukraine, President of Ukraine Leonid Kuchma in 1995, 2002 and 2003 and Prime Minister Valery Pustovoytenko in 1997 to China.

Despite the frequency of visits during that time, Ukraine and the People's Republic of China did not realize the potential of bilateral cooperation, and the declarations approved were rather protocol than substantive ones. The Ukrainian-Chinese relations have become a strategic partnership in 2010 and 2013. The Parties have realized the importance of bilateral relations as China's policy globalizes and Ukraine's desire to participate in these projects. The fruitful results of the bilateral meetings were reflected in the Joint Statement on the Comprehensive Enhancement of Ukrainian-Chinese Friendship and Cooperation Relations in 2010, the Joint Declaration on Establishing and Developing Strategic Partnership Relations between China and China in 2011, the Friendship and Cooperation Agreement between Ukraine and the PRC 2013 Joint Declaration on Further Deepening of Strategic Partnership Relations 2013 and the Program of Development of Strategic Partnership Relations between Ukraine and China for 2014-2018 ${ }^{1}$.

The mechanisms for regulating bilateral relations are the Commission for Cooperation between the Government of Ukraine and the Government of the

\footnotetext{
1 Місце України в глобальних стратегіях Китаю Міжнародний центр $\begin{array}{lr}\text { перспективних } & \text { досліджень. } \\ \text { http://www.icps.com.ua/assets/uploads/images/files/china_mesto_s.pdf }\end{array}$

URL:
} 
PRC, the Parliamentary Group of the Verkhovna Rada of Ukraine for InterParliamentary Relations with the PRC, and the China-Ukraine Friendship Group. The Confucius Institute and the Ukrainian House in Beijing play an important role in cultural and educational contacts.

In September and October 2013, during his visit to Central and Southeast Asian countries, Chinese President Xi Jinping put forward the idea of implementing the One Belt - One Way project - international trade development strategies to promote economic cooperation between countries along the Economic Belt Silk Road "and" Silk Road of the 21st Century". The project was designed to enhance the streamlining of the free flow of economic factors and the efficient allocation of resources, as well as to further integrate the market and accelerate regional economic cooperation, which should benefit all participants. The result may also be the emergence of a large-scale free trade zone from the northwestern provinces of China, Central Asia, to Central and Eastern Europe. About three billion people live along the project path, which gives reason to talk about the huge potential of the market that can reach the project ${ }^{2}$.

The "One Belt and One Way" project is an active search for a new model of international cooperation, which will undoubtedly serve as a positive impetus and energy for world development. This project aims to build and strengthen interconnections on the continents of Asia, Europe and Africa, an interconnected partnership between neighboring countries in the interests of creating a multi-vector, integrated network of cooperation, comprehensive, independent, balanced and sustainable development. The five main goals of the project are: 1) strengthening political coordination - strengthening intergovernmental cooperation, deepening the integration of interests, promoting political mutual trust, reaching new consensus in cooperation; 2) intensification of construction of a single road network; 3) development of trade by eliminating trade barriers, reducing trade costs, improving the speed and quality of economic operations in the region; 4) financial integration, increase in currency flows due to the transition to settlements in national currencies; 5) strengthening of closeness between peoples - cultural and scientific exchanges, strengthening of cooperation in the field of media, tourism, education ${ }^{3}$.

2 Трофимчук А.П. Перспективи приєднання України до проекту “Один пояс, один шлях" / А.П. Трофимчук // Журнал “Міжнародні відносини” Інституту міжнародних відносин Київського національного університету імені Тараса Шевченка. Серія Економічні науки. 2016. № 9/ URL: http://journals.iir.kiev.ua/index.php/ec_n/article/view/3060.

${ }^{3}$ Vision and Actions on Jointly Building Silk Road Economic Belt and 21st-Century Maritime Silk Road / National Development and Reform Commission (NDRC), People's Republic of China. URL: http://en.ndrc.gov.cn/newsrelease/201503/t20150330_669367.html 
The project will enable the Silk Road countries to adjust their economic policies towards wider and deeper regional cooperation, jointly to form an open, tolerant, balanced and profitable regional economic cooperation structure, as well as to build a single transport infrastructure from the Pacific ocean to the Baltic Sea, deepening trade ties with the elimination of barriers, free trade, accelerating freight delivery times, increasing foreign exchange flows, expanding the practice of national currency payments, human contacts, facilitating the creation of a new algorithm for cooperation in the region ${ }^{4}$.

The scale of investment in the "One Belt - One Way" project is estimated at trillions of dollars. Thus, according to the Asian Development Bank, it is necessary to invest in infrastructure in the Asia-Pacific region alone about 750 billion a year ${ }^{5}$.

This way China's plans for the country by 2020 include the construction of 72 new airports, 43 thousand kilometers of highways, 22 thousand kilometers of railways.

Analyzing the legal system of the PRC, it should be noted that it is a "Chinese-specific" socialist legal system. Characterizing the legal system of the People's Republic of China, TV Stepanova emphasizes the need to distinguish the following features: the rule of socialist ideology; concentration of power in the hands of the ruling CCP; supervision and control of the CCP over other state authorities and society; planned economy; collectivism; high role of corporate rules in the system of sources of law; insufficient systematization of legislation, inaccessibility of regulatory materials for citizens, institutions and enterprises ${ }^{6}$.

China's legal system belongs to the Far Eastern group of legal systems, characterized by ancient legal traditions and modern legislation. The prevailing norms of morality over the rules of law in the regulation of certain issues of public life is one of its features. Overall, the organization of the legal system in the PRC is close to the "standards" of the Romano-German legal family. The basic law of the state is the Constitution adopted in 1982,

${ }^{4}$ Кошовий С. А. Економічний пояс великого шовкового шляху: транспортний вимір / С. А. Кошовий // Китаєзнавчі дослідження. 2014. № 1-2. С. 52

${ }^{5}$ Yougang Chen Chinese infrastructure: The big picture / Chen Yougang // McKinsey Global Institute, McKinsey \& Company. URL: http://www.mckinsey.com/globalthemes/winning-in-emerging-markets/chinese-infrastructure-the-big-picture

6 Степанова Т. В. Идентификация правовой системы Китайской Народной Республики: вопросы теории : автореф. дис. ... канд. Юрид. Наук : спец. 12.00.01 “Теория и история государства и права; история политических и правовых учений” / Т. В. Степанова; Владимирский юридический институт Федеральной службы исполнения наказаний. Владимир, 2010. С. 14. 
the next level is constitutional laws, then the normative acts of public authorities and management are located.

According to the provisions of the Law of the People's Republic of China on Lawmaking of 15.03.2000, the rule of law should be understood to mean established and / or sanctioned by the state and provided with mandatory, formal rules of conduct or principles ${ }^{7}$.

At the same time, it is worth noting the very tangible influence of centuries-old traditions of Taoism and Confucianism, on the realms of understanding of law and its implementation. Also, a characteristic feature of the current period of existence of the PRC legal system is its gradual and qualitative modernization in accordance with the requirements of the development of public relations.In turn, the legal system of Ukraine, by its key features, is of Romano-German type. The main source of law is a legal act, the sources of law are also acts of national and international law. Ukraine is a country of codified law.

The hierarchy of normative legal acts is headed by the Constitution of Ukraine. The international treaties ratified by the Verkhovna Rada of Ukraine are an integral part of its legal system. Additional sources of law are legal practices, regulations, legal precedent.

According to NM Krestovskaya, "One of the tendencies in the development of the law of Ukraine is its close interaction with the principles and norms of international law. The process of approximation of the legal system of Ukraine and the countries of Europe implies the interdependence of international and national law" ${ }^{\prime 8}$.

\section{Legalization activities under the laws of Ukraine and China}

By giving a general description of the legal system of Ukraine and the PRC, we can move to an analysis of the content of legalization activities and the identification of the main types of legal procedures.

Legalization is a type of legal activity carried out by an authorized entity to bring certain objects to the state in accordance with the current legislation, and its results and implementation procedures are formalized in written legal acts and have legal significance.

The content of the legalization activity is disclosed in legal procedures related to the erection of certain objects in a position in accordance with the law in force.

\footnotetext{
${ }^{7}$ Про правотворчість : Закон КНР від 15.03.2000 p. URL: http://chinalawinfo.ru/other/ law_legislation

${ }^{8}$ Крестовська Н. М., Матвєєва Л. Г. Теорія держави і права. Підручник. Практикум. Тести : підручник / Н. М. Крестовська, Л. Г. Матвєєва. К.: Юрінком Інтер, 2015. С. 572.
} 
The form of legalization activity consists of two elements: internal and external. Internal components include: subjects of legalization, the nature of the actions of these entities, the procedural mode of activity, ways of organizing the activity, causation. The external form includes both legal acts that are formed during the legalization activity and those in which the result of the legalization procedure is recorded.

The Subjects of legalization - public or private entities having the authority to carry out legalization activities. But along with the powers of such entities, a significant role is attached to the level of their professionalism and legal culture. Thus, the subject of legalization must not only be knowledgeable in law, legal and drafting technology, but also be a carrier of a high level of legal culture, and its behavior must correspond to the essence of socially active legal behavior.

Participants in the legalization activity are also individuals or their groups (witnesses, experts), who assist the activity of the subjects in the process of solving them issues related to the legalization of certain objects.

Participants should distinguish those interested in the results of legalization from persons who do not participate in the legalization activity. The objects of legalization are certain actions or activities; material goods (property, funds); documents; certain conditions; personal, non-property related rights (intellectual property, copyright); subjects of law; state power. In the process of performing the legalization activity, legal actions are performed - external acts of behavior of the subjects of the legalization activity, through which the result of the legalization procedure is achieved. But to achieve such a result requires the implementation of certain operations - a set of interrelated actions aimed at achieving local goals. The means of legalization are legal norms, certain legal evidences, methods, objects of phenomena and actions that ensure the achievement of the necessary result of such activity. Methods of legalization are specific ways of achieving the intended result by the specific means stipulated a legal case. They are vowels, based on scientific knowledge, and are compulsory. Equally important is the high level of knowledge of the rules of legal technology and technology that is the subject of such legalization. The result of the legalization activity is the adoption of a written legal act, which is the result of the respective operations and actions achieved through certain methods and means by the subjects of the legalization activity. Classification of types of legalization activities can be performed by different criteria. Thus, if we take as a classification criterion the nature of the activity, it becomes possible to distinguish the following types: law-making - raising the position, which is enforced by the adoption of the law (for example, legalization of law, the Law on Amnesty of Funds, etc.), on the relevant 
objective (current) law; enforceable - raising a position on the relevant objective (current) law, which is carried out due to the adoption of the act of application of the law (the procedure of state registration of legal entities). If we consider as a classification criterion the status of the subject of carrying out the legalization activity, then it becomes possible to distinguish the following types: public-legal - legalization activities carried out by entities that are endowed with state-power powers (for example, consular legalization);private law - the legalization activities carried out by entities that are endowed with private legal powers (for example, the director of a private enterprise). The most developed is the classification of types of legalization activities, where the degree of demand for certain legalization procedures in society is used as a classification criterion. According to this criterion, distinguish: procedures for legalization of traditional relations of society (for example, recognition of state power, legalization of funds, confirmation of validity of documents, issuance of permission to perform certain activities); procedures for the legalization of unconventional social relations (eg, euthanasia, prostitution, firearms, drugs, etc. $)^{9}$.

In the context of the organization of relations between Ukraine and the PRC, the procedures for legalizing business are of particular importance, namely: procedures for verifying the validity of documents and procedures for granting certain entities the right to engage in certain activities (especially in the business sector). Authentication of documents and signatures, seals, stamps affixing them, as the most important type of legalization activity, is the activity of competent bodies (private and publiclegal), aimed at establishing, certifying, validation of the competent seals on the documents and signatures and compliance with the law of their country of origin ${ }^{10}$.

This type of legalization activity is carried out in the following forms: Notarization. Notarization is an activity related to the system of bodies and officials entrusted with the obligation to certify rights as well as facts of legal value.

Notarial activities are linked to the system of bodies and officials charged with the obligation to disclose rights, as well as facts of legal value. Notarization is usually sufficient to produce documents within their country of origin. The originals of the registration and a number of other company documents are certified by the seal of the state registering authority, and notarized copies of the constituent documents, such as charter, constituent

9 Манько Д. Г. Легалізація в механізмі дії права: монографія / Д. Г. Манько. Херсон: ОЛДІ-ПЛЮС, 2014. С. 119.

${ }_{10}$ Манько Д. Г. Легалізація в механізмі дії права: монографія / Д. Г. Манько. Херсон: ОЛДІ-ПЛЮС, 2014. С. 169. 
agreement, etc., are usually notarized. It is also advisable notarization of documents defining ownership ${ }^{11}$.

Apostillation - the procedure for verifying the validity of documents outside the country of origin by affixing an apostille, which is either a separate letter bearing the name "Apostille", which is attached to a document certifying it, or a stamp with the same name and set strictly defined content. In this case, the apostille should be understood as a simplified procedure for the legalization of documents produced (drawn up and notarized) in the territory of one of the signatories to the 1961 Hague Convention ${ }^{12}$.

Countries that have acceded to the 1961 Hague Convention (Ukraine is one of the acceding countries) are considered to be valid documents bearing the Apostille stamp, which is the same as any other type of certificate, or a separate letter with the name "Apostille", which is attached to a document that certifies whether a stamp with the same name and set strictly defined content. In particular, the apostilization of documents is necessary for opening an account with a bank, establishing a representative office or a subsidiary, as well as for other contacts with official bodies outside the country of origin of documents.

Consular law. It is a certificate of authenticity of the signature of the official, his status and, where appropriate, the seal of the authorized state body on the documents and acts, as well as compliance with their laws of the country of residence. In practice, foreign documents intended for use in the territory of Ukraine can be legalized in the territory of the country where these documents are issued, or directly in Ukraine.

Initially, the document is certified by the Ministry of Foreign Affairs or other authorized body of the state in whose territory it was issued, and then legalized at the consular office of Ukraine in that state. In the second case, the foreign document is first certified by the diplomatic mission or consular post of the country in whose territory the document was issued, and then legalized by the consular service of Ukraine. In both cases, notarized translation of the document in a specific language may be required ${ }^{13}$.

International legal aid agreements - consularization and apostille are not required if the international treaty provides for the abolition or simplification of these procedures. An example is the Convention on Legal Assistance and

${ }^{11}$ Нотаріат в Україні [Текст] : підручник / В. В. Комаров, В. В. Баранкова ; Нац. унт “Юрид. акад. України ім. Я. Мудрого”. Х. : Право, 2011. С. 27.

${ }_{12}$ Конвенція, що скасовує вимогу легалізації іноземних офіційних документів : Гаазька конференція з МПП; Конвенція, Міжнародний документ від 05.10.1961 URL: http://zakon0.rada.gov.ua/laws/show/995_082

${ }^{13} \mathrm{O}$ порядке консульской легализации официальных документов в Украине и за рубежом : инструкция, утв. Приказом МИД Украины от 15 июля 1997 г. № 98-од // ВВР Украины. 1997. № 7. С. 17-36. 
Legal Relations in Civil, Family and Criminal Matters, signed in Minsk on January 22, 1993, to which Ukraine is a party ${ }^{14}$.

In addition, Ukraine has also signed legal aid agreements with the PRC, the Republic of Poland, the Republic of Lithuania, the Republic of Moldova, the Republic of Georgia, the Republic of Estonia, the Republic of Latvia, Mongolia, the Republic of Finland.

The significance of this type of legalization activity for Ukraine is determined by the influence of globalization and integration tendencies on the existence of modern states. The activities of the competent public authorities of the state aimed at establishing, certifying, validating the seals and signatures of competent officials on the documents and compliance with the requirements of the law of their country of origin, is an effective means of developing cooperation at the interstate level in the modern world.

Article 29 of the Agreement between Ukraine and the People's Republic of China on Legal Assistance in Civil and Criminal Matters states that documents produced or certified by a court or other competent authority of one Contracting Party (Ukraine - PRC - Aut.) Are valid if available. signature and official seal. In such form, they may be taken by a court or other competent authority of the other Contracting Party without legalization. Official documents drawn up in the territory of one Contracting Party shall have the force of proof of official documents in the territory of the other Contracting Party ${ }^{15}$.

Along with confirming the validity of the documents, the procedures for organizing authorization for certain activities are equally important.

The granting of a permit to engage in certain activities is a kind of traditional legalization procedure, which is expressed in the admission of certain entities to perform certain activities and, in some cases, the legalization of the results of the activities for which the permit documents were to be obtained ${ }^{16}$.

The subjects of this type of legalization can be both private and public entities. This type of legalization mainly reflects the legal relations in the business sphere and is carried out in the following forms: 1) State registration of business entities is recognition by the state of participants of economic turnover. Recognition consists of three basic procedures: a) state

14 О правовой помощи и правовых отношениях по гражданским, семейным и уголовным делам : Конвенция от 22 января 1993 г. // ВВР Украины. 1993. № 1. С. 37.

15 Про правову допомогу у цивільних та кримінальних справах : Договір між Україною i Китайською Народною Республікою від 31.10.1992 URL: http://zakon2.rada.gov.ua/laws/show/156_014

${ }^{16}$ Манько Д. Г. Легалізація в механізмі дії права: монографія / Д. Г. Манько. Херсон: ОЛДІ-ПЛЮС, 2014. С. 172. 
accounting of business entities; b) collecting publicly reliable data on their legal, property and organizational status; c) control over the legality of the emergence, change and termination of the legal status of the entrepreneur; 2) Licensing and patenting of certain types of entrepreneurial activity as state-legal regulation of entrepreneurial activity in the interests of the state, business, personality, society; 3) Issuance of work permits for foreign nationals; 4) Issuance of permits for construction works (and in some cases legalization of self-employed construction); 5) Non-state registration of powers of participants of business activity.

Legalization of business entities in Ukraine may include: one element state registration (for engaging in activities that do not require licensing or patenting); two elements - state registration and licensing (for engaging in activities requiring licensing); three elements are state registration, licensing and patenting (for pursuing activities requiring licensing and patenting).

The subject of legalization in this case is a person with public legal authority.

The state registrar (as the subject of legalization) is an official who, in accordance with the Law, performs state registration of legal entities and entrepreneurs.

A single state register is an automated system for collecting, accumulating, protecting, accounting and providing information on legal entities and entrepreneurs.

State registration of legal entities and natural persons - entrepreneurs is a certificate of the fact of creation or termination of a legal entity, a certificate of the fact of acquiring or withdrawing the status of an entrepreneur as an individual, as well as carrying out other registration actions stipulated by the Law, by entering relevant records in the Unified State Register.

It should be noted that the result of such actions is of legal importance and is drawn up in the form of a certain legal act - an extract from the Unified State Register of the SPD.

The procedure for conducting state registration of legal entities and natural persons - entrepreneurs includes: 1) verification of the completeness of documents submitted to the state registrar and completeness of the information specified in the registration card; 2) verification of documents submitted to the state registrar for the absence of grounds for refusal to hold state registration; 3 ) entering information about the legal entity or individual - entrepreneur in the Unified State Register; 4) registration of state registration and issuance of an extract from the Unified State Register ${ }^{17}$.

\footnotetext{
${ }^{17}$ Про затвердження Порядку державної реєстрації юридичних осіб, фізичних осіб - підприємців та громадських формувань, що не мають статусу юридичної особи : Міністерство юстиції України. Наказ від 09.02.2016p. URL: http://zakon5.rada.gov.ua/ laws/show/z0200-16
} 


\section{Legal algorithms for business legalization procedures in the PRC}

The general algorithm for business legalization in the PRC consists of the following components: 1) legalization of the documents of the founders of the new company; 2) legalization of campaign documents; 3) obtaining a permit for the activity.

In turn, business legalization procedures in the PRC are contained in the PRC Law of 29.12.1993. This act fixes the requirements on the minimum amount of authorized capital, methods and terms of its payment, on the submission of a special report on verification of payment of authorized capital when registering a company.

By the company's creation, it is necessary to apply to the body of registration of companies in accordance with the procedure established by law with the application for registration. Subject to the provisions of this Law, the company registration authority shall register the company as a limited liability company or a joint-stock limited liability company; if the provisions of this Law are not respected, the registration shall not be conducted $^{18}$.

If the provisions of laws, by-laws provide for the need to approve the creation of a company, then before applying for registration should be in accordance with the procedure prescribed by law.

Interested persons may contact the company registration authority for information on company registration information. The company registration authority should provide an opportunity to get acquainted with such data.

The company registration authority issues a Certificate of Business Law to companies established in accordance with the procedure established by law. The date of issue of the Company Business Certificate is the date of creation of the company.

The Certificate of Business Law must include information on the name of the company, location, share capital, actually paid-up capital, sphere of business activity, as well as the name and surname of the legal representative.

If changes occur in the information contained in the Certificate of Business Activity, the company must, in accordance with the procedure established by law, go through the procedure of registration of changes to the information and the procedure of replacement of the Certificate of Business Activity.

A limited liability company set up under this Law shall bear in its name the designation "limited liability company" or "limited company".

18 Про компанії : Закон КНР від 29.12.1993 p. URL: http://chinalawinfo.ru/ economic_law/law_company/law_company_ch1 
A joint-stock limited liability company created under this Law shall bear in its name the designation "limited liability company" or "joint-stock company". When converting a limited liability company into a joint-stock limited liability company, the conditions for establishing a joint-stock limited liability company shall be observed. When converting a joint-stock limited liability company into a limited liability company, it is necessary to observe the conditions of creation of limited liability companies provided for by this Law.

If a limited liability company becomes a joint-stock limited liability company or a joint-stock limited liability company becomes a limited liability company, then all obligations and claims arising from the transformation of the company are transferred to the company after the transformation.

The location of the company is the location of its main office. When creating a company, it is necessary to develop a company charter in accordance with the law. The charter of the company is binding for the company, its members (shareholders), members of the board of directors, auditors, senior executives.

The sphere of business activity of the company is established by the charter and is registered in accordance with the procedure established by law. The company may amend the articles of association and change the scope of business activities, having undergone the procedure of making changes to the registration data. If the business scope of the company in accordance with the laws, by-laws refers to the approved, it is necessary to go through the approval procedure in accordance with the legislation.

The chairman of the board of directors, executive director or director of the company, in accordance with the charter, assumes the responsibilities of the legal representative of the company and is registered in accordance with the law. When changing the legal representative of the company, you must go through the process of making changes to the registration information.

The company can create affiliates. When creating branches, you must apply to the company registration company with the application for registration and obtain a Certificate of Business Conduct. Affiliates have no legal personality; the company is civilly responsible for their activities.

The company can create subsidiaries. Subsidiaries have the status of a legal entity and bear independent civil liability under the law.

The company may invest in other companies; it is forbidden to transform the company in relation to the enterprise-object of investment into a depositor, bears joint and several liabilities for the obligations of such enterprise. 
It should be noted that the report on verification of payment of the authorized capital in China was issued after checking the accounting firm receipt of the company property from the founders in the payment of the authorized capital. This report is required to be issued at the creation of the company (to confirm payment of $20 \%$ of the authorized capital) and at each subsequent contribution.

On March 1, 2014, changes to the Companies Law came into force in China, which abolished the requirements for the preparation of the accounting report on the payment of authorized capital, the minimum amount of authorized capital for companies, the requirements for the obligatory payment of part of the authorized capital by cash and terms of payment of the authorized capital. These norms come into force unless other laws or by-laws provide specific requirements for the size of the authorized capital of companies that are created in certain types of activities, and the founders of the company have the right to independently determine any amount of the authorized capital ${ }^{19}$.

\section{CONCLUSIONS}

It should also be borne in mind that legalization of business between Ukrainian and Chinese entrepreneurs is possible not only through the creation of new companies, but also through the opening of branches and representative offices of already existing companies. In this case, the documents in which the legal status of the companies (Charter, separate protocols and protocol decisions, certificates and statements of registration and registration, founders documents) are subject to legalization. Moreover, the first stage is the legalization of such documents in the country of origin and in the second stage, properly legalized in the country of origin documents are provided for their confirmation and use in the country where the business is planned (in our case, China). Important in these procedures is that China, although included in the list of States Parties to the Convention, abolishes the requirement of legalization of foreign official documents of 05.10.1961 (Apostille), but on special conditions, namely only its regions of Hong Kong and Macao. In turn, Ukraine acceded to the said Convention on December 22, 2003, though as of 2018, the Convention does not extend to the Crimea, as well as to the occupied territories of Donetsk and Luhansk regions.

Thus, the legalization of business by Ukrainian and Chinese entrepreneurs through the opening of branches and representative offices of existing companies is possible provided that the procedures of consular legalization and apostille are performed.

\footnotetext{
${ }^{19}$ Статьи о бизнесе в Китае. SBF URL: http://sbf-group.com/articles/china/company_ law_amendments_2014/
} 


\section{SUMMARY}

Summarizing the study, I would like to emphasize the great role and importance of legalization procedures in the organization of effective and useful partnerships between modern states. In addition, there are some problematic aspects, such as spending time on proper paperwork. In this context, the development of legalization mechanisms through the use of egovernment systems is a promising trend.

\section{REFERENCES}

1. Нотаріат в Україні : підручник / В. В. Комаров, В. В. Баранкова ; Нац. ун-т “Юрид. акад. України ім. Я. Мудрого”. Х. : Право, 2011. $384 \mathrm{c}$.

2. Про компанії : Закон КНP від 29.12.1993 p. URL: http://chinalawinfo.ru/economic_law/law_company/law_company_ch1

3. Про правову допомогу у цивільних та кримінальних справах : Договір між Україною і Китайською Народною Республікою від 31.10.1992 URL: http://zakon2.rada.gov.ua/laws/show/156_014

4. Про правотворчість: Закон КНР від 15.03.2000 p. URL: http://chinalawinfo.ru/other/law_legislation

5. Статьи о бизнесе в Китае. SBF URL: http://sbf-group.com/ articles/china/company_law_amendments_2014/

6. Степанова Т. В. Идентификация правовой системы Китайской Народной Республики: вопросы теории : автореф. Дис... канд. Юрид. Наук : спец. 12.00.01 “Теория и история государства и права; история политических и правовых учений” / Т. В. Степанова; Владимирский юридический институт Федеральной службы исполнения наказаний. Владимир, 2010. 23 с.

7. Трофимчук А. П. Перспективи приєднання України до проекту “Один пояс, один шлях" / А. П. Трофимчук // Журнал "Міжнародні відносини" Інституту міжнародних відносин Київського національного університету імені Тараса Шевченка. Серія Економічні науки. 2016. № 9 / URL: http://journals.iir.kiev.ua/index.php/ec_n/article/ view/3060.

8. Vision and Actions on Jointly Building Silk Road Economic Belt and 21st-Century Maritime Silk Road / National Development and Reform Commission (NDRC), People's Republic of China. URL: http://en.ndrc.gov.cn/newsrelease/201503/t20150330_669367.html

9. Yougang Chen Chinese infrastructure: The big picture / Chen Yougang // McKinsey Global Institute, McKinsey \& Company. URL: http://www.mckinsey.com/global-themes/winning-in-emergingmarkets/chinese-infrastructure-the-big-picture 
10. Конвенція, що скасовує вимогу легалізації іноземних офіційних документів : Гаазька конференція з МПП; Конвенція, Міжнародний документ від 05.10.1961 URL: http://zakon0.rada.gov.ua/laws/ show/995_082

11. Кошовий С. А. Економічний пояс великого шовкового шляху: транспортний вимір / С. А. Кошовий // Китаєзнавчі дослідження. 2014. № 1-2. С. 51-60.

12. Крестовська Н. М., Матвєєва Л. Г. Теорія держави і права. Підручник. Практикум. Тести : підручник / Н. М. Крестовська, Л. Г. Матвєєва. К.: Юрінком Інтер, 2015. 584 с.

13. Манько Д. Г. Легалізація в механізмі дії права: монографія / Д. Г. Манько. Херсон: ОЛДІ-ПЛЮС, 2014. 232 с.

14. Місце України в глобальних стратегіях Китаю Міжнародний центр перспективних досліджень. 2015 URL: http:/www.icps.com.ua/ assets/uploads/images/files/china_mesto_s.pdf

15. O порядке консульской легализации официальных документов в Украине и за рубежом : инструкция, утв. Приказом МИД Украины от 15 июля 1997 г. № 98-од // ВВР Украины. 1997. № 7. С. 17-36.

16.О правовой помощи и правовых отношениях по гражданским, семейным и уголовным делам : Конвенция от 22 января 1993 г. // ВВР Украины. 1993. № 1. С. 37.

17. Про затвердження Порядку державної реєстрації юридичних осіб, фізичних осіб - підприємців та громадських формувань, що не мають статусу юридичної особи : Міністерство юстиції України. Наказ від 09.02.2016p. URL: http://zakon5.rada.gov.ua/laws/show/z0200-16

\section{Information about the author: Manko D. G., Candidate of Juridical Sciences,} Associate Professor at the Department of State and Law Disciplines, International Humanitarian University 33, Fontanska Road str., Odessa, 65009, Ukraine 